\title{
Processes involved in assessing priorities for local level Lepidoptera conservation programmes that aim to achieve global conservation impact
}

\author{
Roger C. Kendrick \\ Senior Officer (p/t), Kadoorie Farm \& Botanic Garden, Lam Kam Road, Tai Po, New Territories, Hong Kong S.A.R., China. \\ Email: moths@kfbg.org
}

Abstract: Identifying viable conservation projects for Lepidoptera that target threatened species depends upon effective identification and execution within a framework of events. This process requires information gathering and analysis, stakeholder discussion and local community involvement, planning, action, monitoring and review. Published working examples from four continents are drawn upon to illustrate all the key stages, focusing on methods for identifying priority areas (complementarity, biodiversity hotspots, habitat distribution, irreplaceability) for conserving threatened Lepidoptera, whilst considering other conservation issues.

Keywords: Biodiversity hotspots, complementarity, community involvement, conservation planning, habitat distribution, irreplaceability, IUCN Red List, Lepidoptera, priority areas, threatened species.

\section{Date of publication (online): 26 January 2011 \\ Date of publication (print): 26 January 2011 \\ ISSN 0974-7907 (online) | 0974-7893 (print) \\ Editor: Richard S. Peigler \\ Manuscript details: \\ Ms \# 02579 \\ Received 22 September 2010 \\ Final received 19 November 2010 \\ Finally accepted 21 December 2010}

Citation: Kendrick, R.C. (2011). Processes involved in assessing priorities for local level Lepidoptera conservation programmes that aim to achieve global conservation impact. Journal of Threatened Taxa 3(1): 1456-1461.

Copyright: @ Kadoorie Farm \& Botanic Garden Corporation 2011. Creative Commons Attribution 3.0 Unported License. JoTT allows unrestricted use of this article in any medium for non-profit purposes, reproduction and distribution by providing adequate credit to the authors and the source of publication

Acknowledgements: The author would like to thank Kadoorie Farm \& Botanic Garden for supporting the author's participation at the 3rd Asian Lepidoptera Conservation Symposium, as well as Dr. Gary Ades and Dr. Michael Lau at KFBG for providing critical advice on the structure and content of this presentation paper and to Mark Sterling and three anonymous reviewers also assisted in tightening up the composition. Lastly, but by no means least, the author extends his thanks to the symposium's organising committee for inviting this paper to be presented at the symposium, and for their endeavour in running the $3^{\text {rd }}$ Asian Lepidoptera Conservation Symposium with such enthusiasm, efficiency and effectiveness, in spite of the many constraints that had to be overcome.

OPEN ACCESS | FREE DOWNLOAD
This paper, a keynote presentation at the third Asian Lepidoptera Conservation Symposium, Coimbatore, October 2010, provides an initial pointer to the key components of a framework that will assist the implementation of Lepidoptera conservation projects, especially those projects focusing on iconic, globally restricted species, by involving local communities in the projects, so that the communities benefit significantly from their contributions to such projects.

In an ideal world, there would not be a need to conserve butterflies, moths, or any other flora or fauna. However, humanity has a long track record of mismanaging natural resources in an unsustainable way, no more so than at the current time, where habitat loss and fragmentation is now so severe that the very fabric of life appears to be in danger of collapse. Asia is at the front line of this issue, due to the long history of human civilization here and the burgeoning human population that now accounts for $60 \%$ of all humans globally in $30 \%$ of the world's land area. The natural land that supports the wealth of biodiversity found in Asia is constantly being impacted upon, through degradation, conversion to other land uses and unsustainable exploitation. In many parts of Asia, little natural habitat remains, thus it would seem that the priority for nature conservation should be to conserve all remaining natural and semi-natural habitats. Unfortunately, wildlife conservation is generally low

\footnotetext{
This article is part of the peer-reviewed Proceedings of the $3^{\text {rd }}$ Asian Lepidoptera Conservation Symposium (3ALCS-2010) jointly organized by the IUCN SSC South Asian Invertebrate Specialist Group (SAsISG); Department of Zoology, Bharathiar University; Zoo Outreach Organisation and Wildlife Information Liaison Development, held from 25 to 29 October 2010 at Coimbatore, Tamil Nadu, India. http://www.zooreach.org/3alcs2010.html
} 
on the list of priorities for many governments, who usually see economic growth and human issues as their priority. However, as natural resources underpin humanity, we would all be well advised to ensure our remaining "natural capital reserves" are not further eroded.

Where does Lepidoptera conservation at the local level fit in? Lepidoptera should be one of the easier taxa to conserve. They are iconic, being the most popular group of insects in the perception of the general public (Feltwell 1995; Young 1997; Leverton 2001; Glassberg 2003). Their ecology makes them good indicators of change in the environment (Pyle 1984; Dennis 1993). They are a relatively easy group to record (Pollard \& Yates 1993; Waring \& Townsend 2003) and identify due to the amount of literature available, even in tropical areas (e.g. Migdoll 1988; Robinson et al. 1994; Woodhall 2005; Kehimkar 2008; Holloway 19832009). These assets make Lepidoptera a good group for conserving natural land through the association of rare species to particular habitats in a landscape. The iconic nature of butterflies and moths also makes it easier to get local communities to adopt a rare butterfly (or moth) as their own conservation flagship, or to provide a mechanism for gaining sustainable income from the forest, giving the community a vested interest in conserving the remaining land of conservation value near to them (Morgan-Brown 2007).

\section{Conservation Framework}

Convincing regional, national and international business interests and governments of the benefits of habitat protection may not be so easy. A comprehensive assessment to support the conservation of any particular area is becoming imperative to successful conservation projects, even for threatened taxa, though a "research to implementation" gap exists (Knight et al. 2008). Fortunately, the Convention on Biological Diversity sets out a Strategic Plan (COP6 2002) (i.e. a framework for conservation policies) that can be used as a model (Fig. 1), which includes specifying conservation projects as actions undertaken to meet a wider ranging set of conservation strategies that are adopted at the national level by all signatory countries.

This symposium's second Key Area (assess priority areas / communities for Lepidoptera conservation initiatives at the local level that has global conservation impact) is, in effect, a strategy for implementing wildlife conservation in general, modified in this case for the conservation of Lepidoptera. Thus we need to address and focus on points four through seven (Fig. 1) to put the strategy into effect. What does it involve? Objectives to meet the strategy must be identified, then actions that will be prescribed. The outcomes of these actions can be assessed and monitored, providing feedback to the project organisers, participants, funders and supporters as to the level of success of the project. Long term projects must be monitored regularly to enable changes to actions where necessary.

\section{Objectives}

For priority area assessment, there are two critical objectives of Lepidoptera conservation that can be defined:

- identify the priority area(s) based upon presence of globally restricted Lepidoptera

- identify local communities open to involvement in conservation of the habitat for the Lepidoptera involved within the priority areas

These objectives should give clear statements of intent and act as a focus for a programme of specific actions that can be grouped under each objective.

\section{Actions - area assessment}

The first objective (identifying priority areas for globally restricted Lepidoptera) can be undertaken with two main programmes, firstly identifying existing knowledge on species and habitats, then assessing those data:

- identify the Lepidoptera species of global conservation concern that occur within the target area - this should involve:

- trawling through published literature for species records, and sourcing other records (collections);

- undertaking IUCN Red List assessments (global, regional and national) for all species found in the target area - see Hoffmann et al. (2008) for an overview of the Red List criteria application for threatened species and Collins \& Morris (1985) for one of the first examples of application at species level;

- surveying sites where possible to confirm the presence of threatened species; 


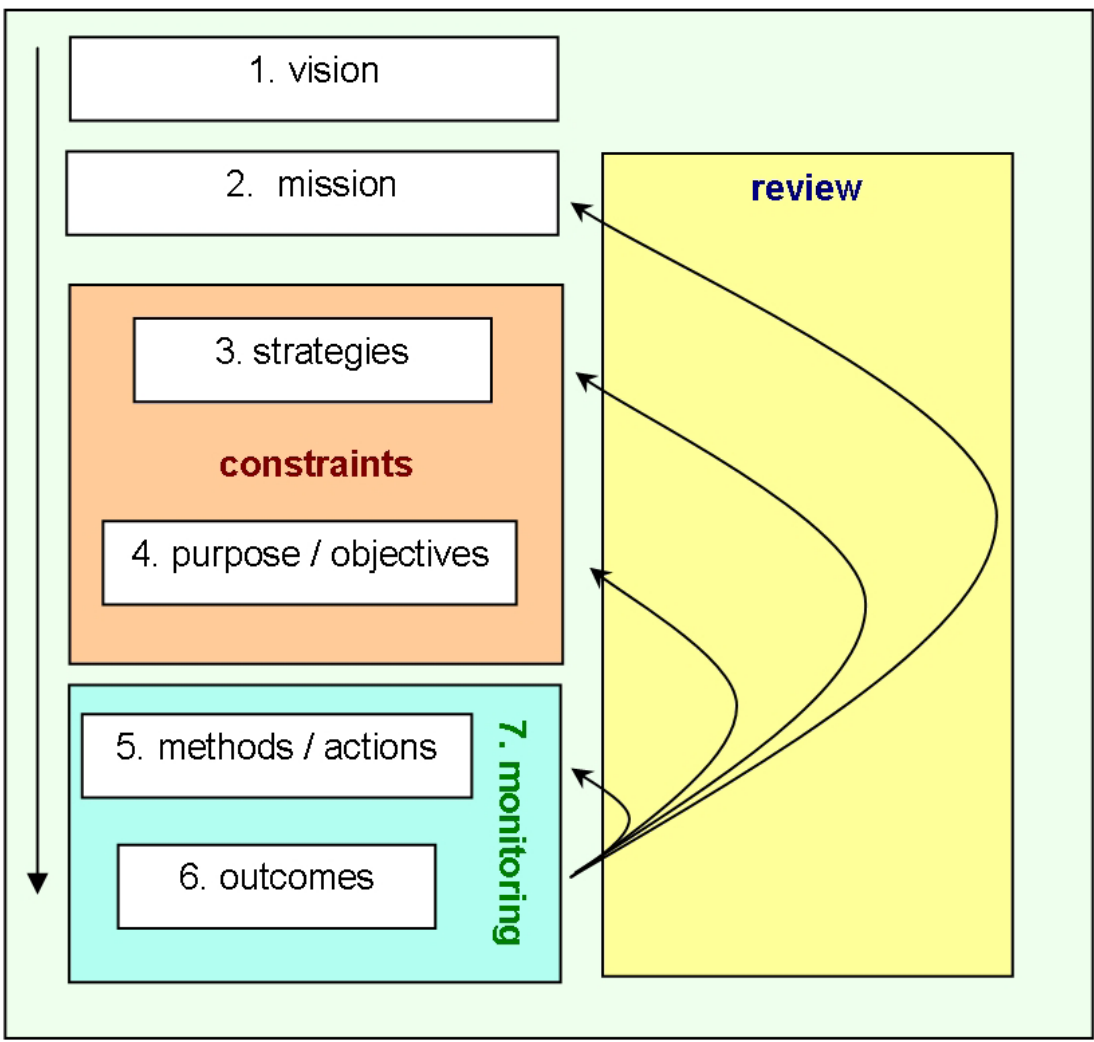

Strategy:

assess priority areas /

communities for

Lepidoptera conservation

initiatives at the local level

that has global

conservation impact

Figure 1. Conservation framework model (based upon COP6 of CBD, 2002)

(http://www.cbd.int/doc/meetings/cop/cop-06/official/cop-06-05-en.pdf)

- profile the ecology of each species of global conservation concern, and try to investigate these species if there is no existing documentation.

Issues that may have to be addressed include: (i) data ownership; (ii) accuracy (i.e. is the data recorded to an appropriate scale) and reliability of data; (iii) impediments to gathering data; (iv) legal requirements to be observed.

Once the baseline data have been gathered, there are different ways these data should be assessed, using the following assessments:

- Complementarity / surrogacy: investigate known data by comparing Lepidoptera diversity with that of other taxa to see if the Lepidoptera complement these other taxa, or are representative of other taxa, and thus by focusing on conserving the habitat containing Lepidoptera other priority taxa are also conserved (working examples: Kitching 1996; Bonn \& Gaston 2005; Williams et al. 2006; Carmel \& Stoller-Cavari 2006; Zafra-Calvo et al. 2010).
- Biodiversity hotspots: map the richness of Lepidoptera diversity, with the aim of identifying areas that have high Lepidoptera species richness (working examples: Danielson \& Treadaway 2004; Balletto et al. 2010 [2009]).

- Habitatdistribution:(metapopulationdynamics/ habitatfragmentation/landscapescaleanalysis); analyse the degree of fragmentation and connectivity of habitats suitable for the target Lepidoptera, working at a landscape scale, so as to evaluate the viability of a population's long term survivability, noting that habitat patches are temporally and spatially dynamic (working examples: Grand et al. 2004; Romo et al. 2007; Early et al. 2008).

- Irreplaceability: assessing the uniqueness of a species or assemblage of species at a particular site (endemic \& threatened species), (working examples: Danielson \& Treadaway 2004; van Swaay \& Warren 2006; Fattorini 2009).

These assessments, though not individually mandatory, are most helpful to make a robust case for 
conserving a particular site (irrespective of why that site is being conserved, as the process is applicable to all flora and fauna) or landscape. Each method has its own strengths and weaknesses, and where a target species occurs in an area that has good results from all four methods (i.e. the area also has other complementary functions, such as other threatened taxa and high ecosystem service value, is a hotspot for Lepidoptera biodiversity and also other taxa, is part of a larger, unfragmented mosaic of natural habitats and is highly irreplaceable due to a high number of endemic species), then the target site should be relatively easy to conserve. A good working example showing a multiple analysis approach is given by Rouget et al. (2004).

\section{Actions - community involvement}

The second objective (identifying and involving local communities) is critical to any conservation project being successful. Identifying the stakeholders involved in land use issues for a potential or actual wildlife conservation site, then fully engaging them as early as possible in the planning phases of a project will usually result in much clearer understanding of the benefits wildlife conservation will bring to the stakeholders. Benefits may include economic improvement, through (for example) ecotourism, sericulture or butterfly ranching, cultural or spiritual improvement and health, through the provision of ecosystem services (Chan et al. 2006; Miller et al. 2008).

Critical stakeholders should include the following:

- chairperson (someone seen as incorruptible, unbiased and capable of providing guidance on good governance)

- representative of the conservation project proponent

- local residential community representative(s)

- regional / national NGO representative

- regional / national government department(s) representative(s)

- local business community representative

- local / regional educational institutions (secondary and tertiary)

Once the critical stakeholders have been identified they should be brought together to ensure everyone is at the same level of understanding. This requires the conservation project leadership to have assessed all the available knowledge pertaining to the project (the results from the assessments) and also to identify gaps in the knowledge (Knight et al. 2008). At the first stakeholder meeting these gaps can be highlighted and hopefully addressed.

There are issues regarding data, and the following questions will have to be addressed to the satisfaction of all stakeholders:

- who knows what?

- $\quad$ are there significant data gaps?

- what are the significant impediments to gathering and sharing data?

- who owns the data?

- what are the data based upon (observation / records / specimens ... )

- how accurate are the data?

- how are the data kept and shared?

- are there any training or capacity building needs amongst the stakeholders?

Once the full facts have been disclosed, the stakeholders to the project will be in a position to decide upon the best way to proceed.

A couple of examples of community involvement spring to mind - the world famous Ornithoptera ranching operations in Papua New Guinea have been operating for 32 years (Hutton 1983), and highlight sustainable operations that provide a local income and benefit a globally threatened taxon (Clark \& Landford 1991). More recently, Morgan-Brown (2007) has documented the same approach in Tanzania, with a similar effect on conserving butterfly populations and their habitats and significantly improving the lives of the villagers involved, to the point where other villages are planning to follow suit. However, it has been observed that practices involving ecotourism may not be as beneficial, owing to unsustainable use of resources and the limited capacity of most natural areas to support the numbers of visitors required to benefit the local communities involved (e.g. MacKinnon et al. 1986; Hannah 1992; Wells \& Brandon 1992; Swarts 2000).

\section{Resources}

Actions in any project can only take hold when there are sufficient resources. It is assumed that the conservation project will assess what resources are required prior to commencement of the project. There are a number of critical steps that determine whether 
there are sufficient resources, but the preparation of an action plan (for species or for habitat - e.g. Bourn \& Warren (1998)) based upon the National Biodiversity Strategy Action Plan (each country signatory to the Convention on Biological Diversity has recently submitted its fourth NBSAP, see the CBD website for details) should be the starting point and will address resource issues.

The action plan should consider the background assessment work mentioned above, plus practical issues, such as legal constraints, sources of funding, manpower, logistics, equipment and responsibility for completion of specific actions. Once prepared, the action plan should be implemented.

\section{Monitoring and Review}

Feedback to stakeholders, participants, project funders and the public is critical to keep the momentum of a conservation project. Good news is always well received and may well help with the project's continuation and support, especially from local communities. Reviewing projects also provides a mechanism to evaluate how successful a project is, whether it is achieving the targets, and whether alternative or modified strategies, objectives and actions need to be formulated to improve the overall success towards achieving the vision.

Consequently, it is imperative that conservation projects have measurable targets and milestones that can be evaluated during the project and upon completion, such that the project can be seen to be a transparent process and have a positive outcome for both the wildlife (Lepidoptera in the context of this article) and the communities that have a vested interest in the project.

\section{REFERENCES}

Balletto, E., S. Bonelli, L. Borghesio, A. Casale, P. Brandmayr \& A.V. Taglianti (2010 [2009]). Hotspots of biodiversity and conservation priorities: A methodological approach. Italian Journal of Zoology 77(1): 2-13.

Bonn, A. \& K.J. Gaston (2005). Capturing biodiversity: selecting priority areas for conservation using different criteria. Biodiversity and Conservation 14: 1083-1100.

Bourn, N.A.D. \& M.S. Warren (1998). Species Action Plan: ADONIS BLUE Lysandra bellargus (Polyommatus bellargus). Butterfly Conservation, East Lulworth, England, $21 \mathrm{pp}$.
Carmel, Y. \& L. Stoller-Cavari (2006). Comparing Environmental and Biological Surrogates for Biodiversity at a Local Scale. Israel Journal of Ecology \& Evolution 52: 11-27.

Chan, K.M.A., M.R. Shaw, D.R. Cameron, E.C. Underwood \& G.C. Daily (2006). Conservation Planning for Ecosystem Services. PLoS Biology 4(11): e379. DOI: 10.1371/journal. pbio.0040379.

Clark, P.B. \& A. Landford (1991). Farming Insects in Papua New Guinea. International Zoology. Yearbook 30: 127131.

Collins, N.M. \& M.G. Morris (1985). Threatened Swallowtail Butterflies of the World. The IUCN Red Data Book. IUCN, Gland Switzerland, vii +401 pp., 8 plates.

COP6 [Conference Of Parties to the Convention on Biological Diversity] (2002). Report of the Open-Ended Inter-Sessional Meeting on the Strategic Plan, National Reports and Implementation of the Convention on Biological Diversity. Annex. Item 3: Strategic Plan for the Convention. 10-19. accessed online at http://www.cbd.int/ doc/meetings/cop/cop-06/official/cop-06-05-en.pdf, 15 September 2010.

Danielsen, F. \& C.G. Treadaway (2004). Priority conservation areas for butterflies (Lepidoptera: Rhopalocera) in the Philippine islands. Animal Conservation 7: 79-92. doi:10.1017/S1367943003001215

Dennis, R.H.L. (1993). Butterflies and climate change. Manchester University Press, Manchester, England, $\mathrm{xv}+302 \mathrm{pp}$.

Early, R., B. Anderson \& C.D. Thomas (2008). Using habitat distribution models to evaluate large-scale landscape priorities for spatially dynamic species. Journal of Applied Ecology 45: 228-238. doi: 10.1111/j.13652664.2007.01424.x

Fattorini, S. (2009). Assessing priority areas by imperilled species: insights from the European butterflies. Animal Conservation 12: 313-320. doi:10.1111/j.14691795.2009.00251.x

Feltwell, J. (1995). The Conservation of Butterflies in Britain past and present. Wildlife Matters, Battle, England, ix $+233 p p$.

Glassberg, J. (2003). Butterflies through Binoculars: A Field Guide to Butterflies in the Boston - New York - Washington Region. Oxford University Press, New York, ix+160pp., 40 plates.

Grand, J., J. Buonaccorsi, S.A. Cushman, C.R. Griffin \& M.C. Neel (2004). A multiscale landscape approach to predicting bird and moth rarity hotspots in a threatened pitch pine - scrub oak community. Conservation Biology 18(4): 1063-1077.

Hannah, L. (1992). African People, African Parks: An Evaluation of Development Initiatives as a Means of Improving Protected Area Conservation in Africa. Agency for International Development, Bureau for Africa, Biodiversity Support Program and Conservation International. Washington, 76pp. 
Hoffmann, M., T.M. Brooks, G.A.B. da Fonseca, C. Gascon, A.F.A. Hawkins, R.E. James, P. Langhammer, R.A. Mittermeier, J.D. Pilgrim, A.S.L. Rodrigues \& J.M.C. Silva (2008). Conservation planning and the IUCN Red List. Endangered Species Research 6: 113-125.

Holloway, J.D. (1983-2009). The Moths of Borneo parts 1 \& 3 to 18. Malaysian Nature Journal 37: 1-107. 38: 157-317. 40: 1-165. 43: 57-226. 47: 1-309. 49: 147-326. 51: 1-242. 52: 1-155. 53: 1-188. 55: 279-486. 58: 1-529. 60: 1-268. 62: 1-240 \& Southdene Sdn. Bhd., Kuala Lumpur (parts 3, 6 \& 18); also on-line at http://www.mothsofborneo.com/ accessed 20 September 2010.

Hutton, A. (1983). Butterfly farming in Papua New Guinea Oryx 19: 158-162.

Kehimkar, I. (2008). The Book of Indian Butterflies. Bombay Natural History Society, Mumbai, xvi $+497 \mathrm{pp}$.

Kitching, I.J. (1996). Identifying complementary areas for conservation in Thailand: an example using owls, hawkmoths and tiger beetles. Biodiversity and Conservation 5: 841-858

Knight, A.T., R.M. Cowling, M. Rouget, A. Blamford, A.T. Lombard \& B.M. Campbell (2008). Knowing but not doing: selecting priority conservation areas and the research-implementation gap. Conservation Biology 22(3): 610-617.

Leverton, R. (2001). Enjoying Moths. T \& A D Poyser, London, $\mathrm{xi}+276 \mathrm{pp}$.

MacKinnon, J.K., G. Child \& J. Thorsell (1986). Managing Protected Areas in the Tropics. IUCN, Gland, Switzer, 295pp.

Migdoll, I. (1988). Ivor Migdoll's Field Guide to the Butterflies of Southern Africa. New Holland, London, 256pp.

Miller, J.Y., J.C. Daniels \& T.C. Emmel (2008). Planning for tomorrow: the future of entomological investments. Florida Entomologist 91(1): 139-144.

Morgan-Brown, T. (2007). Butterfly Farming and Conservation Behavior in the East Usambara Mountains of Tanzania. MSc Thesis, Graduate School of The University of Florida, $55 \mathrm{pp}$.

Pollard, E., \& T.J. Yates (1993). Monitoring butterflies for ecology and conservation. Chapman \& Hall, London, xiii $+274 \mathrm{pp}$
Pyle, R.M. (1984). Handbook for Butterfly Watchers. Houghton Mifflin, New York, xvi+280 pp.

Robinson, G.S., K.R. Tuck \& M. Shaffer (1994). A Field Guide to the Smaller Moths of South-East Asia. Malaysian Nature Society, Kuala Lumpur, 309pp.

Romo, H., M.L. Munguira \& E. García-Barros (2007). Area selection for the conservation of butterflies in the Iberian Peninsula and Balearic Islands. Animal Biodiversity and Conservation 30(1): 7-27.

Rouget, M., B. Reyers, Z. Jonas, P. Desmet, A. Driver, K. Maze, B. Egoh, R.M. Cowling, L. Mucina \& M.C. Rutherford (2004). South African National Spatial Biodiversity Assessment 2004: Technical Report. Volume 1: Terrestrial Component. South African National Biodiversity Institute, Pretoria, viii+77pp. (not including appendices).

van Swaay, C.A.M. \& M.S. Warren (2006). Prime Butterfly Areas of Europe: an initial selection of priority sites for conservation. Journal of Insect Conservation 10: 5-11.

Swarts, F. (2000). The Pantanal in the 21 st Century: For the Planet's Largest Wetland, an Uncertain Future. in Swarts, F. (ed.) The Pantanal of Brazil, Bolivia and Paraguay. Hudson MacArthur, Gouldsboro, PA, USA, 287pp.

Waring, P. \& M. Townsend (2003). Field Guide to the Moths of Great Britain and Ireland. British Wildlife Publishing, Hook, Hampshire, England, 432pp.

Wells, M. \& K. Brandon (1992). People and Parks: Linking Protected Area Management With Local Communities. World Wildlife Fund. US-AID, 99pp.

Williams, P., D. Faith, L. Manne, W. Sechrest \& C. Preston (2006). Complementarity analysis: Mapping the performance of surrogates for biodiversity. Biological Conservation 128: 253-264.

Woodhall, S. (2005). Field Guide to Butterflies of South Africa. Struik, Cape Town, 440pp.

Young, M. (1997). The Natural History of Moths. T \& A D Poyser, London, xiv+271pp.

Zafra-Calvo, N., R. Cerro, T. Fuller, J.M. Lobo, M.Á. Rodríguez \& S. Sarkar (2010). Prioritizing areas for conservation and vegetation restoration in post-agricultural landscapes: A Biosphere Reserve plan for Bioko, Equatorial Guinea. Biological Conservation 143: 787-794. 